\title{
The Responsiveness of Bureaucracy in Implementing Free Health Care Service in Sidenreng Rappang Regency, Indonesia
}

\author{
Basra \\ Suratman \\ Rifdan \\ Andi lhsan \\ Universitas Negeri Makassar, Makassar, South Sulawesi, Indonesia, Jln. Bonto Langkasa, Kampus UNM Gunung Sari \\ Postal Code 90222; basramakka@gmail.com, suratmannur@yahoo.com, rifdan@unm.ac.id, andiincan@gmail.com
}

\section{Doi:10.5901/mjss.2015.v6n6s1p567}

\begin{abstract}
The aim of this research is to find out and analyze the implementation of bureaucracy responsiveness principle in implementing free health care service policy in Sidenreng Rappang regency based on: bureaucracy's attitude in responding complaints, service in providing health care, and response in involving and empowering service user in health care service system. The result of this research concludes that the implementation of bureaucracy responsiveness principle in implementing free health care service in Sidenreng Rappang Regency is not fully optimal. It is proven by: (1) Health Official Bureaucrat shows friendly and committed attitude toward the cleanliness, togetherness, and disciplines in providing health care service and in accordance to the implementation of bureaucracy responsiveness principle in providing health service; (2) Properly respond user's complaints related to the planning program, but the response to complaints related to program implementation, monitoring and evaluation of the program is not maximally administered or less responsive; (3) Empowerment/service user involvement, including participative program from all the stakeholder component gives positive impact and implication toward the bureaucrat's working performance in executing free health care service.
\end{abstract}

Keywords: responsiveness, bureaucracy, policy implementation

\section{Introduction}

Health Care Service provision is a fundamental right for all Indonesian people. It is immensely important for Indonesian government to implement good governance principles in executing public service to its people, including health service, fair treatment, responsiveness and service efficiency. Such goal can only be achieved by building holistic and sustainable health care service which meant to improve health awareness, willingness and ability to live healthy to all of Indonesian people.

Responsiveness is one of important public service dimension, an indicator of service related to apparatus responsiveness to any society complaints and needs that demand service as regulated in the law. Bureaucracy poor ability in responding can trigger the sense of truth crisis. High economic and politic dynamic due to truth crisis are things beyond the ability of bureaucracy to anticipate which make the lives of the society even worse and uncertain. Initiative and creativity of bureaucracy in responding is not enough to decrease the crisis and its impact. Society expects quick response toward the crisis are left with disappointment because the bureaucracy response tends to be reactive and less effective. Various problems in the center and regional area still unresolved without comma or even remain untouchable which make the society lost their trust easily toward the ability of the bureaucracy to deal with the crisis.

The afore separate mentioned phenomena above successfully describe how fragile society's trust is and government legitimacy. The reason behind this fragility is that the government along with its bureaucracy has failed their society to be a capable institution which protects and fight for public interests and needs. Power oriented institution has made the bureaucracy growing more irresponsive and insensitive toward their society call for help. Recent domination exposed by the bureaucracy in both economic and politic aspects have created many distortions in executing public services which tends to escalate and worsen the happening economy and politic crisis even more.

This research is conducted to find out and analyze the implementation of bureaucracy responsiveness principle in 
implementing free health care service policy in Sidenreng Rappang regency based on: bureaucracy's attitude in responding complaints, service in providing health care, and response in involving and empowering service user in health care service system.

\section{Review of Related Literatures}

Etymologically, bureaucracy means "power behind the table". According to Lance Castle bureaucracy is "paid and functioned people in government body". Bastard bureaucrat, a short mean sentence used by Blau and Meyer, (2000, $p$. 3 ) the "bureaucracy" term used by Blau and Meyer does not refer to government inefficiency and infectivity, because in their opinion that is not the real meaning of "bureaucracy".

Blau (2000, p. 6), the term bureaucracy is synonymously used with inefficiency, although Bureaucracy is actually a powerful institution with the capability to increase the potential capacity toward good and bad things, because basically bureaucracy is a neutral rational administration instrument in bigger scale. Bureaucracy has the power to make the imperialistic expansion easily and exploit the economy to destruct underdeveloped countries and the needy.

Bureaucracy is intended as a rationally approved authority system by many rules. According to Widodo (2002, p. 50), bureaucracy has vital roles in organizing the government and development. By that vital roles, bureaucracy is classified into three different things namely bureaucrat, politic, and profession. Bureaucracy as a profession refers to particular occupation which requires certain special requirement as opposed to other kinds of existing profession, means that position in bureaucracy can only be seated by those who possess expertise in specific field. Service Bureaucracy is basically an organization which directly interacts with the society. In line with Service Bureaucracy, Thoha (2003, p. 78) stated that the service provided by the government bureaucracy has the exclusivity to use the authority and power within the institution to force the entire civilian to obey the approved the rules and regulations.

Responsiveness as an indicator of service is related to the ability of the government apparatus in responding society`s needs. Dwiyanto (2008, p. 51), explained responsiveness as the organizational capability to know the needs of the society, arrange and prioritize the agenda and service, as well as develop public service programs to meet the need and aspiration of the society. In brief, responsiveness in this case refers to the harmony of service and the demands of the society toward the given service.

An approach policy implementation approach is introduced by Van Meter and Van Horn called $A$ Model of the Policy Implementation (1975, p. 463). This model suggested that policy implementation goes linear with politic decision, executor and public policy performance. This model explains that policy performance is influenced by several related variables, those are; (1) standard and policy target/benchmark and goal of the policy; (2) resources; (3) characteristic of the organization in charge; (4)executor's attitude; (5) inter-organizations communication and programs; (6) social environment, economy, and politic.

\section{Research Method}

The design of this research is descriptive qualitative. This research analyze bureaucracy's responsiveness in implementing free health care service policy in Sidenreng Rappang Regency.

The sources of the data in this research are bureaucrat apparatus and the society as the public user (stakeholders) who are experienced and educated about the health condition in Sidenreng Rappang regency, based on their main job and function which consists of: (1) Primary data collected from informants statements, and other deliberately gathered information related to the focus of the research through observation and interview. Those informants including Head of Health Official, Head of Clinic, Medic and Nursing Practitioners, Health Official Staffs, Society Respected Figure, onGovernment Organization (NGO); (2) Secondary data sources are relevant documentation in the form of written documents (local regulation, literary books, scientific writing, national and international published journal, printed mass media or electronic/internet, main program development, strategic plan, and annual plan), pictures, and statistical data about the development of public health service, main instrument of the research is the researcher per se, aided by other research instruments such as; observation guidance, interview guidance, and written document.

\section{Research Findings and Discussion}

The research findings of the implementation of bureaucracy responsiveness principle in implementing free health care service in Sidenreng Rappang are as follow: 


\subsection{Bureaucrat's attitude in responding service user complaints}

The bureaucrat is responsive in responding to free health care service user complaints which reflect the existence of the sense of responsibility based on integrity to achieve both vision and mission of the organization maximally, responsiveness in addressing complaints can finally be done collectively in every level of health service department.

Despite the implementation of responsiveness principle, there still many complaints coming from the user, but some complaints have properly responded by the bureaucrat apparatus by giving friendly response, showing honesty, maintaining cleanliness, solid teamwork, and working in discipline.

The findings of this research can be illustrated by the following table below:

Table 1: Bureaucrat apparatus attitude in responding the service user toward the implementation of Bureaucracy Responsiveness Principle in Implementing Free Health Care Service in Sidenreng Rappang Regency.

\begin{tabular}{|l|l|l|l|}
\hline Research Focus & Ideal Condition & Research Findings & Synthesis \\
\hline Bureaucrat apparatus attitude in & Rahayuningsih (2008, & Bureaucrat apparatus are friendly & Responsiveness and higher \\
responding the service user toward & p. 1) attitude as a & responding the complaints by: & commitment showing by the \\
the implementation of Bureaucracy & simplistic expression of & smiling, greeting, being polite, & bureaucrat apparatus in serving \\
Responsiveness Principle in & how do we like or dislike & committing to discipline, & will minimalize user complaints \\
Implementing Free Health Care & problems. & in order to achieve the goal \\
Service in Sidenreng Rappang & & togetherness in performing free & optimally. \\
Regency & health care service. & \\
\hline
\end{tabular}

Source: Research data analysis result, 2015

\subsection{Bureaucrat apparatus response in addressing service user complaints}

Bureaucrat has to quickly respond all complaints from the users in order to catch up with their duties and functions. In short, responsiveness refers to the harmony between service programs/activities and the needs/aspiration of the society.

Health Official Management is a set of activities conducted systematically to produce effective and efficient result by: planning, executing the plan, monitoring and evaluating. All of the activities are a unit that tightly related and sustainable.

Sidenreng Rappang Health Official arrange strategic and performance based plan to deal with any existing health problems. Strategic plan can be described in main development program and top program that will become the working platform for the next five years while the performance based plan will be integrated yearly.

Bureaucrat apparatus service in addressing user/society's complaints toward the implementation of free health care service in Sidenreng Rappang Regency goes through several main steps namely planning, plan execution, monitoring and evaluation.

The previous explanation regarding research findings on Bureaucrat apparatus response in addressing service user complaints can be reconstructed by the following table:

Table 2: Bureaucrat apparatus response in addressing service user complaints toward the implementation of bureaucracy responsiveness in implementing free health care service policy in Sidenreng Rappang Regency.

\begin{tabular}{|c|c|c|c|}
\hline Research Focus & Ideal Condition & Research Findings & Synthesis \\
\hline \begin{tabular}{|l|} 
Bureaucrat apparatus \\
response in addressing \\
service user complaints \\
toward the implementation of \\
bureaucracy responsiveness \\
in implementing free health \\
care service policy in \\
Sidenreng Rappang Regency
\end{tabular} & $\begin{array}{l}\text { Dwiyanto (2008, p. } 51) \\
\text { explained responsiveness as the } \\
\text { organizational capability to know } \\
\text { the needs of the society, arrange } \\
\text { and prioritize the agenda and } \\
\text { service, as well as develop } \\
\text { public service programs to meet } \\
\text { the need and aspiration of the } \\
\text { society. }\end{array}$ & $\begin{array}{l}\text { Bureaucrat apparatus start responding } \\
\text { user complaints by identifying the } \\
\text { needs of the society then arranging } \\
\text { and prioritizing service agenda in the } \\
\text { program, executing the program, } \\
\text { monitoring and evaluating the } \\
\text { program. In fact, the program does not } \\
\text { work the way it is supposed to be. Not } \\
\text { to mention monthly monitoring and } \\
\text { evaluation in the clinics only } \\
\text { conducted once in a three month. }\end{array}$ & $\begin{array}{l}\text { Good planning is not } \\
\text { accompanied by optimal } \\
\text { and proper plan } \\
\text { execution and } \\
\text { monitoring lead to } \\
\text { unsuccessful program } \\
\text { which fail to address } \\
\text { user complaints and } \\
\text { their needs. }\end{array}$ \\
\hline
\end{tabular}

Source: Research data analysis result, 2015 


\subsection{Bureaucracy responsiveness to involve and empower service user}

Service user empowerment can only be achieved by direct participation of the society in executing government program. Empowerment can be translated as a process of helping human or society by developing capability of the society, changing mindset and behavior of the society, and organizing the society. Society potential which can be developed such as effort of the society, seeking information capability, program organization, and other meaningful capability needed to meet their demand and deal with the problems.

Organizing society as an attempt to organize and manage event or program can be beneficial in forming working committee, distributing job responsibility, supervising, and planning activities.

Society do not have any role in health service at the beginning, but nowadays it is time to involve and empower them actively in the system, not only as the service user but also giving them the responsibility to organize in order that they can actively participate in developing and improving health service, so that they can be proud of themselves and the implementation of free health care service runs well.

The previous explanation regarding research findings on Bureaucrat apparatus response in addressing service user complaints can be reconstructed by the following table:

Table 3. Bureaucracy`s responsiveness to involve and empower service user toward the implementation of bureaucracy responsiveness in implementing free health care service policy in Sidenreng Rappang Regency.

\begin{tabular}{|l|l|l|l|}
\hline Research Focus & Ideal Condition & Research Finding & Synthesis \\
\hline $\begin{array}{l}\text { Bureaucracy`s } \\
\text { responsiveness to involve and } \\
\text { empower service user toward } \\
\text { the implementation of } \\
\text { bureaucracy responsiveness } \\
\text { in implementing free health } \\
\text { care service policy in } \\
\text { Sidenreng Rappang Regency }\end{array}$ & $\begin{array}{l}\text { Madekhan Ali (2007, p. } \\
\text { 86) stated that society } \\
\text { empowerment as a } \\
\text { form of participation to } \\
\text { liberate them from } \\
\text { mental and physical } \\
\text { dependence. }\end{array}$ & $\begin{array}{l}\text { Health service user is involved and } \\
\text { empowered properly by the } \\
\text { bureaucracy apparatus. Reality } \\
\text { shows that the user is given time and } \\
\text { space so that the user can directly be } \\
\text { involved in planning, executing, } \\
\text { monitoring and evaluating the } \\
\text { program. Service user is actively } \\
\text { spreading information to the public, } \\
\text { giving suggestions or meaningful } \\
\text { input, and participating in health } \\
\text { service program. }\end{array}$ & $\begin{array}{l}\text { Bureaucrat apparatus } \\
\text { involving/empowering service user } \\
\text { in health service program, this is a } \\
\text { good effort to improve the society } \\
\text { by encouraging them and providing } \\
\text { burdening them with their main } \\
\text { business. }\end{array}$ \\
\hline
\end{tabular}

Source: Research data analysis result, 2015

\subsection{Bureaucracy responsiveness principle implementation in implementing Free Health Care Service in Sidenreng Rappang Regency}

Free Health Care service policy implementation in many levels of Health division in Sidenreng Rappang regency related to the implementation of bureaucracy responsiveness principle implementation in the perspective of public service includes bureaucrat apparatus attitude, service, and involvement/empowerment in responding user complaints.

Responsiveness is the organizational capability to know the needs of the society, arrange and prioritize the agenda and service, as well as develop public service programs to meet the need and aspiration of the society. User service satisfaction can only be achieved if the Health Official Bureaucracy apparatus in giving/providing service in health facility make the standardized service quality as their guidance. Public service quality improvement is positive attitude character change of the government bureaucracy in serving service user by putting aside the differences and fair treatment (equality) to all society. The society demands justice in health service, honesty and transparency from the bureaucrat in carrying out their duty. A satisfying service is influenced by the competence of the Health Official Bureaucrat apparatus, at least holistic positive attitude and behavior change to give the best service starting from the leader to his/her structural subordinates. This thing can impact positively to the transformation of public service bureaucracy.

Bureaucracy apparatus tends to be irresponsive and less aspirative toward the needs of its people. On the other hand, bureaucracy apparatus has important roles to execute government program and to perform public service.

The implementation of free health care service in Sidenreng Rappang regency improves year to year based on the Human Development Index and Life Span Expectation indicators. In terms of positive attitude change, the number is low but still growing. Bureaucracy apparatus respond user complaints friendly by: smiling, greeting, being polite, committing 
discipline, maintaining cleanliness and togetherness in performing public service.

They respond to user complaints by showing positive attitude, such as properly addressing every complaint, being friendly to the service user, being cooperative in responding the complaint, and trying to provide possible solution to the problems.

The Reality Analysis based on bureaucracy apparatus attitude in responding complaints can be symmetrically and visually transformed in the following figure:

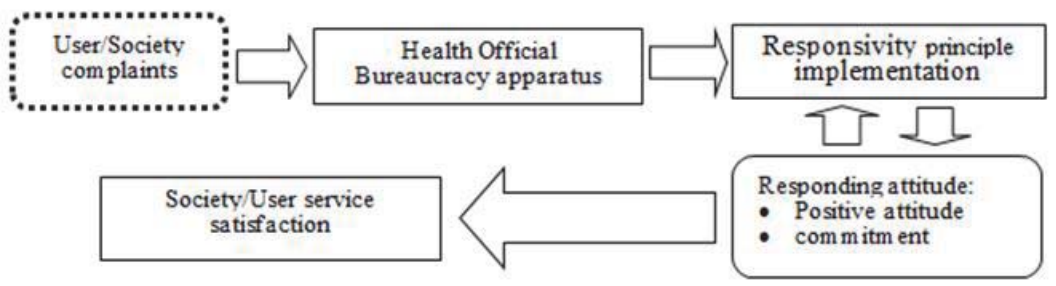

Figure 1. Bureaucracy apparatus attitude framework in responding

The implementation of bureaucracy responsiveness principle based on responding attitude is done to reflect positive attitude and higher commitment toward cleanliness, teamwork, and discipline of the bureaucrat apparatus in performing the service will minimalize service user's complaints and positively impact the policy and satisfy the society.

Based on the result of the analysis toward the implementation of responsiveness principle in implementing free health care service, propositions can be formulated as follow:

Proposition 1: Positive attitude and higher commitment toward cleanliness, teamwork, and discipline exposed by the bureaucracy apparatus in serving public health will minimalize user complaints and positively impact to the bureaucracy responsiveness in implementing public policy.

Analysis in bureaucracy service perspective towards the implementation of the policy in Sidenreng Rappang regency shows the way bureaucracy response to user complaints by firstly executing planned program, monitoring and evaluating the program.

Positive attitude and higher commitment from the bureaucracy apparatus in responding the complaints need to be effectively and efficiently be administered as soon as possible. Those kinds of response are given by the bureaucracy apparatus in all level of public service facility including Health Official, Regional Public Hospital, and Clinics.

The sequence of free health care service in Sidenreng Rappang regency always refers to the regional strategic plan perspective that the most important aspect to be targeted in program planning process is to identify the needs and aspiration of the society as the subject of the policy implementation. Planning process begins by formulating problems in Clinic Level Planning and combined with suggestions from discussion in village level, district level, regency level, then province level and final discussion in national level. The findings of the research shows that Health Official planning in Sidenreng Rappang regency is arranged to deal with the service user complaints toward the implementation of free health care service.

Development planning process in Sidenreng Rappang regency conducted based on the bottom up mechanism. The involvement of the society in arranging the plan as a concrete proof that the Health Official really listen to their society as the target of the policy.

Bureaucracy apparatus service in responding to the public health facility development in Sidenreng Rappang regency year 2014 is less than 106 new villages, 72 villages are equipped with Poskesdes (village based clinic unit) and only 42 villages are equipped with Pustu (assisting clinic unit). Ideally, each village is equipped with 1 Pustu and 1 Poskesdes which carry different main duty and function. Medical practitioners gap placement in every level of public health facility in both regional public health hospital and clinics. Even if this is a free health care service, society still need to spend money on transportation fee to reach the health facility. Local government in Sidenreng Rappang regency is inconsistent to fund the budget aimed at the free health care service provision. The inconsistency is due to:

1. Supply and total rehabilitation of public health facility including medical instruments totally depends on central government. The availability of the fund to finance the free health care service takes a long time up to 5 years or more to provide, solely depends on the commitment of the central government to provide the budget.

2. Medical practitioner placement gap in different areas due to less optimal distribution of medical practitioner in 
all areas.

3. Transportation fee from home to public facility is not include in free health care service. This thing needs government consideration in issuing new public policy in order to avoid any potential complaints from the society.

Free health care budget from the government is less effective because the fund for the program in Sidenreng Rappang regency is based on a signed MoU between Sidenreng Rappang regency and South Sulawesi province government. There is budget sharing between the two parties to finance the free health care service, $60 \%$ from Sidenreng Rappang regency and 40 \% from South Sulawesi province government. This cooperation between two different levels of government does not always run smooth and lack of funding. In the end, it impacts the success of the program and the complaints keep rising.

Bureaucracy apparatus service in responding user complaints can be formulated based on the empirical fact and the implementation of free health care service and its relevance to the perspective of organization management can be visualized by the figure 2 .

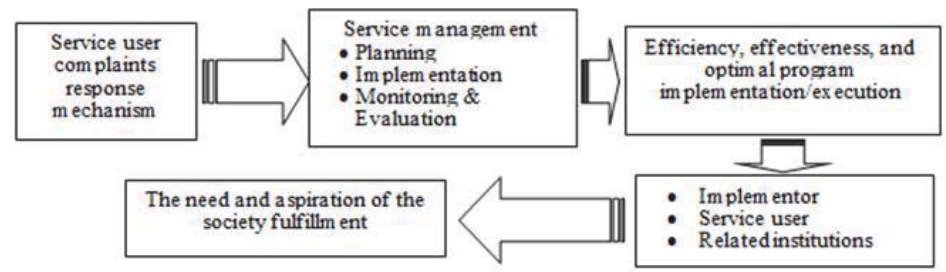

Figure 2. Visual relation of bureaucracy apparatus service in responding user complaints through program implementation/execution.

Based on figure 2 above, it is obvious that bureaucracy apparatus has done well in terms of planning the program, lacks in monitoring and evaluating the program which means that less response toward the implementation/execution, monitoring, and evaluation of the program.

The researcher formulates a specific proposition based on the figure above. The proposition has something to do with bureaucracy service in responding service user complaints toward the implementation of bureaucracy responsiveness principle in implementing free health care service.

Proposition 2: Responsive service based on management organization through optimal planning, implementation/ execution, and effective yet efficient monitoring and evaluation fulfills the need and aspiration of the society.

Research on bureaucracy responsiveness perspective in involving and empowering service user toward the implementation of free health care policy in Sidenreng Rappang regency concludes that the society along with the bureaucracy has properly involved and empowered in providing free health care. Society's participation is really needed in arranging plan and policy/decision making.

Empirical facts show that Health Official bureaucracy apparatus has empowered service user toward the implementation of bureaucracy responsiveness principle in implementing free health care service in Sidenreng Rappang regency. Higher participation from the society to take part in succeeding the program really impact the implementation of free health care service to make it more optimal.

The data of Health Official Office in Sidenreng Rappang regency has increased in number of Clinic visitor to get free health care service and treatment in the all health facility during this last years.

All societies are encouraged to take part by the bureaucracy apparatus in assessing/evaluating free health service in all health facilities by undergoing satisfaction survey and giving suggestion and constructive input in order to improve the existing free health care service. They are also actively participated in programs which designed to anticipate extra additional charge of health service by taking part in Arisan Jambang Sehat Mudah Kredit, Mom and Baby`s Saving program, and SIAGA program. SIAGA is a program that insists all husbands to accompany their wives through the birth delivery process.

Free health care service implementation in Sidenreng Rappang regency based on empirical facts and the system of service user empowerment gathered throughout this research and its relation can be visually formulated in the figure below: 


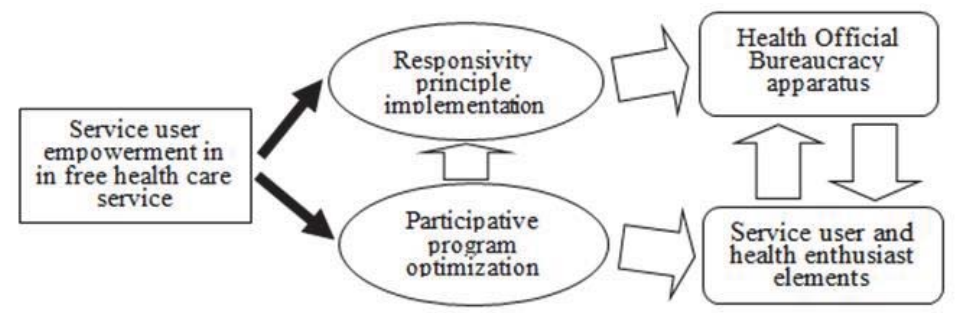

Figure 3. Framework concept of service user empowerment system in free health care service

Service user involvement/empowerment in free health care service policy implementation tends to directly impact and boost working performance of health official bureaucracy apparatus in positive way.

The implementation of Bureaucracy responsiveness in implementing free health care service policy based on user empowerment, including participative programs which combine all stakeholder components positively impact bureaucracy apparatus responsiveness in providing free health care service.

Another proposition is formulated to describe user empowerment system implemented by the bureaucracy apparatus as an indicator of health care service. The proposition is as follow:

Proposition 3: Service user empowerment and bureaucracy apparatus responsiveness are proven supportive to improve the power of service user to generate optimal and the most out of health care service.

Empowerment can be defined as an effort to arouse and triggered awareness of society's potential and attempt to improve such potential to the point that liberate society's dependence. Society empowerment is meaningful attempt to develop their potential to contribute, participate and actualize by giving them encouragement, chances, and protection in various activities.

Bureaucracy responsiveness principle implementation in implementing free health care service in Sidenreng Rappang relies on public service management application which focused on three indicators called bureaucracy apparatus attitude in responding to complaints, bureaucracy apparatus service in responding complaints through program execution/implementation, and bureaucracy apparatus respond through the service user empowerment.

Bureaucracy responsiveness principle implementation in implementing free health care plays crucial role to tackle the issue of user complaints which in the long run satisfied and fulfilled the needs, demands and aspiration of the society. Responsiveness is really needed in public serving because it accommodates the organization the ability to identify the needs of the society, arranging agenda and prioritizing service and last but not least developing service programs to meet the needs and aspiration of the society.

\section{Conclusion and Suggestion}

The implementation of bureaucracy responsiveness principle in implementing free health care service in Sidenreng Rappang shows Health Official bureaucracy apparatus as policy implementor is not fully achieved the goal that targets the local society. Weaker responsiveness from the bureaucracy to anticipate society complaints has failed Health official as government institution in providing proper free health care service.

Health Official bureaucracy has shown positive attitude but not that optimal in implementing bureaucracy responsiveness principle. They respond to complaints friendly by smiling, greeting, being polite, being committed, maintaining cleanliness, togetherness and discipline in serving for public health service.

Responses related to user complaints in terms of planning program is well established, but not optimally executed in terms of monitoring and evaluation.

The implementation of bureaucracy responsiveness principle in implementing free health care service by involving and empowering service user including participative program from all stakeholders positively impact the provision of free health care service.

\section{References}

Ahmad, Jamaluddin. (2011). Perilaku Birokrasi dan Pengambilan Keputusan. Makassar: Badan Penerbit Universitas Negeri Makassar. Akib, Haedar. (2010). Implementasi Kebijakan: Apa, Mengapa, dan Bagaimana? Jurnal Administrasi Publik, 1(1), p. 10-15. 
Beetham, David. (1990). Bureaucrasy, translated by Saliat Simamora. Jakarta: Bumi Aksara.

Blau, Peter M. and Meyer, Marshall W. (2000.) Bureaucracy in Modern Society. Jakarta: Prestasi Pustakarya.

Dilulio, Jhon J. (ed.). (1994). Deregulating the Public Service: Can Government be Improved? Washington D.C: The Brookings Institution.

Dwiyanto, Agus. (2008). Reformasi Birokrasi Publik Indonesia. Yogyakarta: Gajah Mada University Press.

Kausar, AS. (2009). Sistem Birokrasi Pemerintahan di Daerah dalam Bayang-Bayang Budaya Patron-Klien. Bandung: PT. Alumni

Miftah, Thoha. (2003). Birokrasi dan Politik Indonesia. Jakarta: PT. Raja Grafindo Persada.

Rakhmat. (2009). Teori Administrasi dan Menajement Publik. Jakarta: Pustaka Arf.

Rozi, Syafuan. (2006). Zaman Bergerak Birokrasi DirombakPotret Birokrasi dan Politik di Indonesia. Jakarta: Pustaka Pelajar.

Said, M.M. (2007). Birokrasi di Negara Birokratis. Malang: UPT. Penerbitan Universitas Muhammadiyah Malang.

Siagian, Sondang P. (2000). Teori Pengembangan Organisasi. Jakarta: Bumi Aksara.

Van Meter, Donald. and Van Horn, Carl. (1975). the Policy Implementation Process: Aconceptual Frame Administration and Society. In Parson, Wayne. (Eds), Public Policy: Pengantar Teori dan Praktik Analisis Kebijakan. Kencana Prenada Media Group.

Widodo.J. (2002). Akuntabilitas dan Kontrol Birokrasi. Surabaya: Insan Cendekia.

Zaithamal, A., Parasuraman., and Berry, L. (1990). Delivering Quality Services Balancing Custumer Perceptions and Expectations. New York: The Free Press. 